\title{
The International Trading System and Its Future
}

\author{
Rachel McCulloch*
}

November 2010

This chapter describes the evolution and structure of the international trading system, focusing on the tension between the fundamental GATT/WTO principle of most-favored-nation (MFN) treatment and the proliferation of discriminatory trading arrangements, including regional agreements as well as new versions of special and differential treatment of low-income countries. It also discusses the increasing pressure to use the enforcement power of the GATT/WTO system to achieve member compliance with social norms in the areas of labor and environment. The chapter concludes by considering some significant challenges that currently face the international trading system and possible directions of the system's evolution in response to these challenges.

Prepared for the Oxford Handbook of International Commercial Policy, edited by Mordechai E. Kreinin and Michael G. Plummer. Thanks are due to Chad Bown, Peter Petri, and Max Kreinin for helpful suggestions.

*Rosen Family Professor of International Finance, Department of Economics and International Business School, MS021, Brandeis University, Waltham, MA 02454-9110, USA; Email: mcculloch@ brandeis.edu; web: http://people.brandeis.edu/ rmccullo/. 


\section{Introduction}

The international trading "system" comprises many thousands of unilateral, bilateral, regional, and multilateral rules and agreements among more than two hundred independent nations. Atop this complex and rapidly evolving mass of political and economic arrangements is the World Trade Organization (WTO), with 153 members that together account for nearly all of world trade. ${ }^{1}$ Created in the Uruguay Round of multilateral negotiations as a successor to the General Agreement on Tariffs and Trade (GATT), the WTO provides a legal and institutional framework for national policies that directly or indirectly affect international trade among its members. Like the GATT, the primary goal of the WTO is to promote freer and more predictable conditions of trade. However, practice has gradually moved away from the principles that shaped the original GATT. In the WTO, nondiscrimination among trading partners remains a fundamental principle, as laid out in the original GATT (now known as GATT 1947) and also in the updated GATT 1994 produced in the Uruguay Round. Yet GATT rules also allow for preferential (i.e., discriminatory) policies, and these have become an increasingly important feature of the international trading system. Likewise, although reciprocity has always played a key role in GATT/WTO procedures for multilateral trade negotiations and dispute settlement, the scope of non-reciprocal arrangements intended to benefit poorer countries has steadily expanded.

The WTO is the latest embodiment of multilateral efforts to promote cooperation among trading nations that began even before the end of World War II. At the 1944

\footnotetext{
${ }^{1}$ An overwhelming majority of the 153 members are developing countries, with 32 of the poorest classified as least developed countries (LDCs); 29 additional "observer" nations are working toward WTO membership. http://www.wto.org/english/thewto_e/whatis_e/whatis_e.htm (accessed 3/8/2010). Significant nonmembers include the Russian Federation and several other major oil exporters.
} 
Bretton Woods Conference, which created the International Monetary Fund (IMF) and International Bank for Reconstruction and Development (World Bank), participating nations also recognized the need for a third institution, to be called the International Trade Organization (ITO). The ITO was designed to prevent a resurgence of the protectionism of the pre-war period and continue the efforts toward reciprocal trade liberalization that were already in progress before the onset of the war. In addition to trade policies, the new organization's authority was to include national policies toward foreign investment and business practices. However, plans for the ITO were derailed when the U.S. Congress failed to ratify its ambitious draft charter. In its place, the more limited 1947 GATT treaty emerged as a "temporary" solution, one for which U.S. participation did not require Congressional approval. ${ }^{2}$

Despite its limited scope and resources, the GATT endured for nearly 50 years, its membership (formally, contracting parties or signatories) growing from an initial 23 to 128 by $1994 .^{3}$ Prior to the Uruguay Round, which began in 1986, the GATT had already sponsored seven rounds of multilateral trade negotiations. These had achieved a significant cumulative reduction in tariff rates. By 1986, the trade-weighted average of tariffs on manufactured goods had been reduced to about 6.4 per cent, from about 35 per cent in $1947 .{ }^{4}$ The GATT has thus been credited with a key role in facilitating the massive growth in the volume of world trade during the post-war era (Irwin 2002, 165170).

\footnotetext{
2 The GATT was an agreement rather than a full-fledged international organization and had "contracting parties" rather than members. It came into effect during the ITO negotiations, with the goal of achieving immediate tariff reductions among the 23 participating countries (Hudec 1998).

${ }^{3}$ http://www.wto.org/english/thewto_e/gattmem_e.htm (accessed 3/8/2010).

${ }^{4}$ Crowley (2003) quoting Hoekman and Kostecki (1995).
} 
Yet the GATT left some critical issues unresolved (Crowley 2003). Although average tariff rates had been reduced substantially, stubborn peaks for individual products remained. Some major industries, notably agriculture and textiles and apparel, had been excluded from normal GATT guidelines. Even in covered sectors, importing nations were making extensive use of "administered" protection—-such as antidumping actions, countervailing measures, and voluntary export restraints - to limit competition from abroad. Moreover, GATT rules pertained mainly to trade in tangible goods, a significant limitation with international trade in services growing at a rapid rate. Other issues closely linked to trade but not covered by GATT rules included national policies toward foreign direct investment and intellectual property. And perhaps most central, the GATT provided no effective way to resolve disputes among the contracting parties.

Concerns about these shortcomings of the GATT provided much of the agenda for the ambitious Uruguay Round (1986-1994), which culminated in establishment of the WTO. Yet despite the fanfare surrounding the WTO's birth in 1995, doubts regarding the new organization soon began to materialize. These doubts were heightened by lack of progress in the Doha Round begun in 2001, the first round of multilateral negotiations sponsored by the WTO. Some critics have called for a new Bretton Woods conference to reconfigure the three major international economic organizations and reallocate responsibilities among them. The goal would be to increase their overall effectiveness in addressing problems in global governance not anticipated in the 1940s, including huge bilateral trade imbalances and national efforts to limit climate change.

Section 2 of this chapter describes the evolution and structure of the GATT/WTO system. Section 3 deals with the tension between the fundamental GATT/WTO principle 
of most-favored-nation (MFN) treatment, i.e., nondiscrimination among trading partners, and the trend toward discriminatory trading arrangements, including the proliferation of regional agreements as well as new versions of special and differential treatment of lowincome countries. Section 4 focuses on participation of developing countries in the system and the effort to use special treatment to promote development objectives.

Section 5 discusses the pressure to use the enforcement power of the GATT/WTO system to achieve member compliance with social norms in the areas of environment and labor. Section 6 assesses some significant challenges that currently face the international trading system. Section 7 concludes by considering possible directions of the system's evolution in response to these challenges.

\section{The World Trade Organization}

Notwithstanding repeated threats of its imminent collapse over nearly eight years of negotiations, the Uruguay Round made remarkable headway in addressing some of the most important shortcomings that had plagued the GATT 1947. While negotiators continued the traditional GATT-era work of reducing tariff and non-tariff barriers to manufactured goods trade (average tariff rates were reduced by 40 per cent), they also broke new ground with agreements to bring trade in services, textiles and apparel, and agricultural products into greater conformity with GATT norms. The Round's significant achievements included negotiation of commitments to reduce agricultural subsidies, to phase out the Multifibre Arrangement (over a ten year period) and thus apply the same rules to trade in textiles and apparel as to trade in other manufactured goods, and to strengthen protection of intellectual property rights (with phase-in periods based on 
members' level of economic development). Other agreements improved rules and procedures dealing with a variety of non-tariff measures, including subsidies, technical barriers to trade, and sanitary and phytosanitary measures. The goal of these agreements was to balance member governments' acknowledged need to address domestic concerns against the potential for abuse of such policies as a disguised form of import protection or discrimination among trading partners.

The Uruguay Round also departed from precedent in a fundamental respect. With minor exceptions, all WTO members agreed to comply with the obligations spelled out in all the agreements, which were included in the "Single Undertaking." This need for consensus among all participants was in contrast to the approach used in the Tokyo Round, in which various "codes" governing use of non-tariff barriers were endorsed by only some members, primarily the most advanced countries. Rules in the Tokyo Round codes then applied only to trade among signatories. However, there has recently been discussion of reverting to a system that does not require all members to move toward WTO goals at the same rate. ${ }^{5}$

The most significant departure from the system created by GATT 1947 was a revamping of procedures for settling disputes among trading nations. The WTO Dispute Settlement Understanding (DSU) introduced a systematic rules-based approach to resolving disputes concerning members' alleged failure to meet their WTO obligations. This system is usually described as self-enforcing, in that the WTO itself has no power to police national trade policies. Rather, an affected member must initiate each dispute.

\footnotetext{
${ }^{5}$ Hoekman and Kostecki (2009, 529-530). An approach in which common policies are implemented at different rates is often called "variable geometry," a phrase due to Jacques Delors. However, because it refers to differences in speed of convergence to common policies, it leaves aside the more difficult situations in which there is no agreement on what the common policy should be.
} 
Under the current system, any dispute that cannot be resolved through direct negotiation among affected countries is referred to a panel of three experts, almost always specialists in international commercial relations, e.g., diplomats and trade lawyers. The panel report is intended to provide a neutral judgment as to whether the member has violated GATT/WTO rules. ${ }^{6}$ If the panel affirms that the contested policy is inconsistent with the member's WTO obligations, the member can appeal the decision, amend its policies, or face authorized retaliation from trading partners that have lost market access as a result of the violation. Authorized retaliation (and often merely the threat of retaliatory action)in the form of partners' increased barriers designed to reduce the member's market access by an amount commensurate with the effect of the contested policy-provides the enforcement mechanism that maintains adherence to WTO rules and thus protects members' export market access. The DSU is an important improvement over the GATT system, in which any country could in effect veto a panel decision that was contrary to its political or economic interests.

Similar to the role played by the GATT until the end of the Uruguay Round, the WTO serves as a forum for multilateral trade liberalization negotiations among its members. The current Doha Round, initiated in 2001, is the first round of multilateral negotiations to be held under WTO sponsorship and is thus seen as a test of the new organization's ability to maintain forward momentum in trade liberalization. The stalled round therefore brings the WTO framework into question. But the WTO has important functions separate from its role as the facilitator of multilateral trade negotiations. Most

\footnotetext{
${ }^{6}$ More precisely, the panel report indicates whether the challenged policy is WTO-inconsistent. This broader category also includes "non-violation complaints." In contrast to the more common disputes involving an allegation that a member has violated a WTO rule, these refer to situations in which the complainant has not received the anticipated benefit even though no rule has been violated. Such complaints aim at preserving the balance of benefits intrinsic to reciprocal bargaining.
} 
important is its role discussed above as neutral arbitrator of trade disputes, i.e., in helping to assure that members actually receive the anticipated trade benefits of reciprocal liberalization. The WTO also serves a monitoring and information-dissemination function, again building on its GATT roots. The WTO collects and publishes data on trade flows as well as changes in trade policy undertaken by members between negotiating rounds (members are required to notify the WTO of certain policy changes, such as antidumping actions). Under the Trade Policy Review Mechanism (TPRM), the WTO carries out periodic reviews of each member's trade policy regime; scheduled frequency of review is highest for the largest trading economies. ${ }^{7}$ The results of the reviews, including the responses of member country officials, are made available on the WTO website. Finally, as discussed in section 4 below, the WTO has also continued to expand the role gradually taken on by the GATT in promoting the trade interests of developing countries. ${ }^{8}$

\section{GATT/WTO principles and discriminatory trading}

At the start, the primary goal of the GATT was to promote nondiscriminatory trade liberalization. The fundamental guidelines were nondiscrimination (most-favorednation treatment among signatories), reciprocity, and transparency. MFN treatment was deemed important enough to be the subject of Article I of the GATT 1947, while the

\footnotetext{
${ }^{7}$ This timing scheme is the opposite of what might be recommended, given that it dedicates most resources to the major countries, for which other agencies and organizations already provide ample and often more timely information. Moreover, the review process is influenced by political as well as economic considerations. To avoid controversy, reviewers may fail to emphasize the kinds of information that would be most helpful in ensuring members' adherence to their WTO commitments (Bown 2009, 219-220).

${ }^{8}$ In the early decades, poor countries were termed "less-developed" countries (LDCs). Since adoption of the more optimistic but often inaccurate current terminology, LDC has become the acronym used to designate the least developed countries, i.e., the poorest of the poor.
} 
agreement's preamble called for members to enter into "reciprocal and mutually advantageous arrangements directed to the substantial reduction of tariffs and other barriers to trade" and Article XXVIII required "compensatory adjustment" when previously agreed concessions were modified. The need for increased transparency was expressed in several GATT articles, especially Article X, requiring prompt publication by signatories of new laws and regulations affecting trade, and Article XI, calling for general elimination of quantitative restrictions on trade. The underlying goal was to ensure that foreign suppliers would face known and constant barriers, ones that could be overcome by sufficiently competitive producers. The strong preference specifically for the use of tariffs over quantitative restrictions or other types of trade policies also stemmed from the view that reliance on tariffs would simplify the future process of reciprocal liberalization. The early GATT priorities reflected the negotiating nations' desire to undo the harm to the international trading system that had occurred during the 1930s. The SmootHawley tariffs enacted by the U.S. Congress in 1930 had soon been followed by similar "beggar-thy-neighbor" actions by other countries, as well as discriminatory arrangements such as the United Kingdom's imperial preferences, which entailed lower tariffs on imports from its colonies and dominions. With the United States and England taking the leading roles, negotiators resumed efforts begun before World War II to lower barriers to trade through reciprocal reductions in bound tariff rates (reciprocity), ${ }^{9}$ to replace

\footnotetext{
${ }^{9}$ In the United States, the 1934 Reciprocal Trade Agreements Act authorized the President to conduct bilateral negotiations with major trading partners to reverse the protectionist Smoot-Hawley tariffs on a reciprocal basis. U.S. tariff cuts achieved through these negotiations were then extended to other trading partners through most-favored-nation treatment. Negotiated reductions required no enabling legislation by Congress.
} 
quantitative restrictions and other nontariff barriers by tariff protection (transparency), and to eliminate discriminatory arrangements (most-favored-nation treatment).

The initial success of the GATT in achieving these goals reflected mutual gains to the participating nations, but, given the overwhelming dominance of the United States in the world economy, the key factor was U.S. willingness to abide by GATT principles. Cuts in the first GATT round (1947) reduced U.S. average bound tariff rates by 26 percent (Martin and Messerlin 2007). However, changing conditions gradually diluted U.S. commitment, pushing the contracting parties toward a multi-tier system of responsibilities. The first change was the surge in exports of manufactured goods from Japan and then from four even newer suppliers (Hong Kong, Singapore, Taiwan, and South Korea) collectively termed the Newly Industrializing Economies (NIEs) or Four Tigers. To manage the increase in competing imports, the United States and the European Union used discriminatory policies involving extra-GATT bilateral agreements with individual exporters rather than the GATT's own safeguard procedures (Article XIX), which are meant to be applied on an MFN basis. The result was the spread of negotiated quantitative restrictions, first from Japan ${ }^{10}$ to the NIEs, and then, especially for textiles and apparel, to many additional exporters. By 1974, worldwide trade in textiles and apparel was controlled by the Multifibre Arrangement (MFA), a system of bilateral quotas limiting trade between most of the world's rich importers and most of the world's poor exporters of these products.

At the same time, the list of contracting parties gradually expanded to include more of the world's poor countries. The new signatories were often former colonies of

${ }^{10}$ The United States had already negotiated bilateral trade restraints with Japan for textiles prior to World War II. 
the original participants. Perhaps inevitably in an organization operating on the basis of unanimity, provision for "special and differential treatment" of nations at an earlier stage of economic development expanded far beyond the initial vague commitment in GATT Part IV, which had been added in 1964. Attention to the trade concerns of less-developed nations increased further during the "New International Economic Order" crusade of the 1970s. The issues raised by the increasing majority of poor countries among participants in the GATT/WTO system are discussed below in section 4 .

A final important change in the GATT/WTO system has been the surge in negotiation of preferential trade agreements $\left(\mathrm{PTAs}^{11}\right.$ ) among subsets of participating nations. From the start, the GATT made provision for PTAs in Article XXIV, even though such arrangements represented an explicit departure from the GATT/WTO guiding principle of nondiscriminatory trade among signatories, i.e., most-favored-nation treatment. In the WTO, Article XXIV of the GATT 1994, together with the Uruguay Round "Understanding on the Interpretation of Article XXIV of the General Agreement on Tariffs and Trade," set rules governing PTAs for goods; Article V of the GATS contains corresponding rules for services.

The GATT/WTO position on PTAs recognizes the desirability of increasing trade through voluntary agreements between two or more members. However, there is also the concern that such agreements should facilitate trade among the partner countries without raising barriers to trade with non-partner countries. ${ }^{12}$ Article XXIV therefore places

\footnotetext{
${ }^{11}$ WTO documents refer to these as Regional Trade Agreements (RTAs), even when partner countries are on separate continents.

${ }^{12}$ Even in the absence of higher MFN tariffs, the preferential margin created by a PTA in effect raises barriers to trade with non-partner countries, resulting in trade diversion, i.e., the substitution of partner imports for lower-cost imports from non-partners. Some economists have suggested that countries forming free trade areas should be required to reduce MFN tariff rates to offset this tendency.
} 
some significant restrictions on the common external tariffs applied by members of a customs union as well as the required product coverage, which is supposed to include “substantially all trade.” In practice, however, the GATT/WTO system has taken a laissez-faire attitude, with virtually no effort to ensure that agreements are consistent with the guidelines. Moreover, almost all the new PTAs - the notable exception is the European Union — have been free-trade agreements (FTAs) rather than customs unions with common external tariffs. The result has been what Jagdish Bhagwati termed a "spaghetti bowl" of PTAs, with selective product coverage, lengthy phase-in periods, and complex rules of origin (ROOs). ${ }^{13}$

Beyond an expectation that new PTAs will be notified to the WTO, the rules on preferential trading appear to exercise little if any discipline over such arrangements. In practice, no preferential agreements among GATT or WTO members, whether developed or developing, have ever been challenged by other members. This laissez-faire posture has given rise to increasing concern about the effects of proliferating free trade agreements on progress toward multilateral trade liberalization. This deleterious effect could arise for either of two reasons (Krueger 2007). First, the limited capacity of many countries to conduct international trade negotiations may be taxed by efforts to form PTAs. Second, WTO members' incentives to engage in multilateral liberalization may be lessened to the extent that the benefits derived from current PTA membership would thereby be eroded. However, these concerns do not seem to be discouraging members

\footnotetext{
${ }^{13}$ More lenient rules on preferential trading between developing countries are contained in the Tokyo Round agreements signed in 1979.
} 
from pursuing new PTAs. ${ }^{14}$ Moreover, some theoretical and empirical research suggests

that formation of free trade areas may actually stimulate rather than retard multilateral

liberalization, i.e., that PTAs can act as building blocks rather than stumbling blocks

(McCulloch and Petri 2007; Estevadeordal, Freund, and Ornelas 2008).

\section{Developing countries in the international trading system}

Although the 23 nations participating in the negotiations that produced the original GATT in 1947 included 12 developing countries, in its early days the GATT was disparaged as a "rich man's club." 15 The GATT initially focused almost entirely on trade in manufactured goods, i.e., goods that were then exported mainly by the developed countries, and GATT rules for poor countries were mostly the same as those for rich countries. However, developing countries were accorded special treatment through exemptions from some rules, e.g., permission under Article XVIII to use tariffs and quotas to promote an infant industry or to deal with balance of payments problems (Dam 1970, Chapter 14). Developing countries also benefited via most-favored-nation

\footnotetext{
${ }^{14}$ Pomfret (2007) argues that the extent of PTA formation has been exaggerated by use of faulty measures. He also notes that the most important PTAs in terms of trade volume affected, notably the European Union, coordinate policies in many areas in addition to trade, thereby achieving "deep integration" among their members. Such agreements have complex implications for the health of the multilateral trading system going far beyond the usual trade creation/trade diversion analysis.

${ }^{15}$ Beginning in 1964, the United Nations Conference on Trade and Development (UNCTAD) provided a forum where concerns of poor countries could be aired. The UNCTAD agenda included issues such as one-way trade preferences for manufactured exports of poor countries, stabilization of commodity export prices - primary commodities had accounted for about 80 percent of export earnings of these countries and a non-fuel commodity was the leading export for many - and unconditional grant aid. However, much of the agenda required the cooperation of rich countries for funding or market access. Some parts of the agenda became reality, including the Generalized System of Preferences enacted by most industrialized countries and export-earnings stabilization schemes implemented by the International Monetary Fund and the European Economic Community (EEC).
} 
treatment from the liberalization commitments of the advanced nations without being required to engage in reciprocal opening of their own markets.

The principle of special treatment for developing countries was formalized by the addition in 1966 of Part IV, "Trade and Development," to the GATT. The Tokyo Round went even further with adoption of the Enabling Clause (officially, "Differential and More Favorable Treatment of Developing Countries”) in 1979. The Enabling Clause allows advanced countries to discriminate in favor of poorer countries, and especially the least developed countries - as had already been done through the enactment of the Generalized System of Preferences (GSP). The Enabling Clause also allows developing countries to negotiate preferential trade agreements that do not satisfy the usual GATT criteria as spelled out in Article XXIV. ${ }^{16}$

Notwithstanding their special status, most of the poor countries remained poor, and those that prospered - mainly the NIEs and other East Asian countries — did so through export-oriented growth strategies. Yet these new exporters were soon subjected to discriminatory trade restrictions, and the GATT did little to shield them from policies that violated at least the spirit of its rules. Moreover, even after successive rounds of GATT-sponsored multilateral trade negotiations, labor-intensive manufactured products like shoes and especially textiles and apparel remained highly protected, while world prices of many agricultural products were depressed by generous subsidies in the United States and European Union.

\footnotetext{
${ }^{16}$ For example, such agreements may cover only a limited range of products rather than "substantially all trade" as specified in Article XXIV.
} 
The GATT's special treatment of developing countries turned out to be at best ineffective and perhaps even counterproductive. ${ }^{17}$ To begin with, it was predicated on the assumption now largely discredited that trade liberalization is less desirable for developing countries than for developed countries. Facing less external pressure to open their markets to trade, the developing countries obtained less of the potential benefits to be derived from integration into world markets. Moreover, relieving the developing countries of the requirement for reciprocity meant that these countries remained on the sidelines in shaping multilateral negotiations. The developing countries thus lost the opportunity to exchange access to their own domestic markets (whether as a group or, for some larger countries, individually) for desired liberalization commitments from developed countries. By remaining nonparticipants in the successive rounds of GATT tariff reductions, they also lost the opportunity to contest disadvantageous exceptions to basic GATT rules for specific sectors, especially textiles and apparel and agriculture. Finally, because MFN liberalization reduces the benefits enjoyed by countries with preferential access to important markets, the existence of one-way preferences may retard progress toward global free trade. ${ }^{18}$

By September 1986, when the Uruguay Round negotiations began, the total number of GATT contracting parties had grown to 91, and the majority of the additions were developing countries, including newly independent nations in Africa and elsewhere. More developing nations joined the GATT during the negotiations that eventually produced the WTO, which commenced operation on January 1, 1995 with 128 members.

\footnotetext{
${ }^{17}$ Jones $(2010,24-27)$. Some analysts foresaw the problematic outcome of the Tokyo Round's emphasis on "special treatment" of developing countries. See McCulloch (1983).

${ }^{18}$ In the Doha Round, some beneficiary countries have requested compensation for the erosion of benefits from preferential market access as MFN protection is negotiated downward.
} 
But despite ongoing efforts to provide benefits for poor countries, the operation of the GATT system was still dominated by the concerns of the developed nations, and those concerns continued to play an important role in the Uruguay Round. By 2008, an overwhelming majority of the 153 WTO members were developing countries, with 32 of the poorest classified as least developed countries (LDCs). Yet even with the rapid increase in their numbers, many observers, and especially those representing the interests of poor countries, judge that participation in the Uruguay Round and in the WTO have so far yielded few benefits for these countries.

Of the accomplishments from the Uruguay Round, the eagerly sought dismantling of the Multifibre Arrangement (MFA) proved to be a major disappointment to most developing countries, as China's share of export markets for textiles and apparel exploded and competition among suppliers dissipated quota rents. The Agreement on Trade-Related Aspects of Intellectual Property Rights (TRIPS) has been criticized as causing, at least potentially, an adverse movement in the terms of trade of poorer countries, which are overwhelmingly importers of proprietary technologies created mainly in a few rich countries. ${ }^{19}$ Promised elimination of U.S. and European Union agricultural subsidies has stalled, disappointing middle-income developing countries with comparative advantage in sugar, rice, cotton, soybeans, and other agricultural products. And the Doha Development Round, aimed specifically at addressing post-UruguayRound concerns of poor countries, has been declared dead on numerous occasions.

But laments regarding lack of progress in the Doha Round have tended to overshadow the increasing benefits already being derived by many developing countries

\footnotetext{
${ }^{19}$ In practice, implementation delays and favorable pricing practices, especially for pharmaceuticals, have so far minimized the feared effects.
} 
from another achievement of the Uruguay Round: creation via the Dispute Settlement Understanding (DSU) of an enhanced process that allows members to self-enforce the market access to which their trading partners have agreed. Data on disputes brought to the WTO show a steady stream of WTO self-enforcement actions undertaken by developing countries throughout the WTO era, in contrast to the declining trend of selfenforcement actions undertaken by the developed countries over the same period (Bown and McCulloch 2010). These actions have allowed at least some developing countries to maintain the market access to which they are entitled in situations when trading partners have failed to uphold their WTO commitments.

Yet the ability of developing countries to engage in successful self-enforcement actions remains limited by two important factors. First, most developing countries have small markets for imports. This is partly due to small total demand but also to significant import barriers, which on average are still much higher than those of the developed countries. Since the self-enforcement process relies on the threat of WTO-authorized retaliation, its potency is limited by import market size. Thus, only larger developing countries are in a position to take advantage of the self-enforcement process. In addition, information about foreign actions that reduce market access may be difficult to obtain, especially when the actions in question are less easily observed than new trade barriers. Developing countries have therefore focused their self-enforcement actions on types of WTO violations that are directly observable by exporting firms and governments, especially unjustified application of antidumping measures, rather than on subtler domestic measures that also limit imports. ${ }^{20}$ Although WTO litigation costs of

\footnotetext{
${ }^{20}$ The preponderance of cases involving antidumping may also reflect the global proliferation in this particular form of import protection.
} 
developing countries' self-enforcement actions are already heavily subsidized by the Advisory Center on WTO Law, the significant informational costs of determining when such an action is justified remain a significant deterrent (Bown 2009).

\section{Trade sanctions as a means of enforcing socioeconomic norms}

The WTO is unique among international organizations in possessing an effective system by which its rules can be enforced. As a result, there has been continuing pressure going back to the GATT era to use the WTO to enforce socioeconomic norms shared by a significant number of participating countries. The justification for involving the GATT/WTO is that failure to honor social norms usually confers a cost advantage. A country's failure to meet such norms may therefore be regarded as "social dumping" and treated in an analogous way. The main areas of domestic policy potentially affected are those concerned with environmental protection and labor standards, although as discussed in section 6.2 below, there has been recent discussion of using trade sanctions as a way to force macroeconomic "rebalancing."

Underlying the controversy regarding use of WTO-authorized trade sanctions to enforce socioeconomic norms is that national attitudes regarding environmental protection and labor standards are strongly affected by per capita income - these norms tend to be "luxury goods" whose demand rises along with citizens' incomes. Expecting poor countries to meet the same standards as rich ones may place poor countries at an important competitive disadvantage and may also be economically inefficient. For example, to the extent that labor productivity is higher in rich countries, mutually 
beneficial two-way trade between rich and poor countries may require similar differences in wages. ${ }^{21}$

Poor countries argue that norms should be adjusted to take into account differences in stage of development, pointing out that present labor and environmental conditions in their economies are no worse, and in some cases far better, than those that prevailed in the now-industrialized nations during an earlier era. Although actual GATT/WTO links between market access and social norms have so far been minor, ${ }^{22}$ the issue is poised for greater significance as many developed countries begin to impose broad restrictions on carbon emissions and pressure developing countries, especially large ones like China and India, to make corresponding commitments.

\section{Emerging issues}

It is easy to point to shortcomings in the world trading system that bode ill for the future. The Doha Round had stalled repeatedly even before the onset of the global financial crisis of 2008-9. Despite a trimmed-down agenda, many observers have grown pessimistic about completion of the round. But on the positive side, even the extreme economic disruptions accompanying the global crisis did not give rise to the feared surge in protectionism and defection from WTO disciplines. Although many countries implemented some new protection, this was done almost entirely in ways that did not violate their WTO commitments, i.e., through antidumping and safeguard actions, or by

\footnotetext{
${ }^{21}$ Consider a simple Ricardian model in which labor productivity in the richer country is four times as high in the export industry and twice as high in the import-competing industry as in the poorer country. Twoway trade is then possible only if the richer country's wage rate is at least twice but no more than four times as high as that of the poor country, when both are measured in the same currency.

${ }^{22}$ Their role is greater in preferential agreements. Beginning with the North American Free Trade Agreement (NAFTA), many preferential agreements have explicitly linked market access to environmental and/or labor policies, though these have so far had minimal impact on policies.
} 
raising applied tariffs that were initially lower than the corresponding bound rates (Bown and Kee, 2010).

Meanwhile, the development of an unprecedented bilateral imbalance between the United States and China has placed an increasing strain on a system based on reciprocity, and a continuing surge of new preferential, i.e., discriminatory, trading arrangements has increased the tension between the GATT/WTO's key MFN principle and trade realities. MFN has now come to mean least-favored-nation treatment, i.e., paying the "list price" at the border. Beneficiaries of one-way preferences argue that fairness requires compensation for erosion of benefits when successful MFN liberalization cuts the preferential margin they now enjoy. And finally, the perceived need to reverse the growth of carbon emissions will pose an important new challenge for the WTO, as participating countries seek trade policy measures to deal with "carbon leakage" from countries not willing to join in these efforts. How are these situations likely to play out in terms of evolution of the world trading system?

6.1 The Doha Round. As of late 2010, the stalled Doha Round, which was initiated in November 2001 as the Doha Development Round, had already exceeded the length of any of its predecessors, and with no end in sight. In contrast, even the ambitious and protracted Uruguay Round had required "only" seven years and seven months from inception to signing. Economists and public officials are divided on both the feasibility of completing the round and the importance of doing so. ${ }^{23}$ Some see the lack of progress

\footnotetext{
${ }^{23}$ Martin and Messerlin (2007) review the history of previous rounds of multilateral negotiations in order to evaluate alternative explanations for the Doha Round's lack of progress. In the end they remain cautiously optimistic about the round's eventual success. Baldwin (2009) likewise draws parallels with past rounds, pointing out that the history of past negotiations is also "littered with lengthy stalemates."
} 
as a reflection of the problems inherent in achieving consensus among such a large and diverse group of nations and even question whether there is any future for multilateral trade liberalization along the lines of the GATT rounds of the past. This view gains some credence from the heightened pace at which new preferential agreements have been initiated and concluded over the same period. Moreover, the recent economic woes of the advanced countries have further reduced domestic political support for any new concessions to developing countries.

Even those who argue for completing the round are divided on what is to be gained by doing so. Some see the fate of the Doha Round as significant mostly for what it implies about global support for the WTO as an institution. In this view, a failed round could undermine the WTO's authority in setting and enforcing guidelines for national policies toward trade (Hoekman, Martin, and Mattoo 2009). However, others see a Doha failure mainly as a missed opportunity to continue the GATT/WTO's progress in promoting a more open and transparent trading system. In direct contrast to proposals to further limit the scope of the negotiations as a way to facilitate agreement, Hufbauer, Schott, and Wong (2010) argue for a more ambitious package that would increase anticipated gains for major parties and thus justify the political effort required to bring the round to a successful conclusion. Whether this approach is feasible remains to be seen, but it is certainly true that progress can only be made if each participant perceives a net benefit from going forward; raising the stakes could energize the moribund process. However, with world leaders already challenged by more urgent priorities, it is not obvious where the necessary leadership for a step in this direction can be found. 
6.2 Reducing bilateral imbalances. As the world emerges from the global financial crisis, the need for "rebalancing" supply and demand across countries and continents has become evident. But where does the responsibility for rebalancing lie, and how should it be achieved? Accomplishing this goal during a still-fragile recovery beset with other important international dilemmas, such as the fate of the Euro, poses a formidable challenge.

Many believe that a major appreciation of China's currency is a necessary condition for sustained shrinkage of its bilateral surplus with the United States. If so, is it appropriate for the WTO to become the enforcer of this prescription? Mattoo and Subramanian (2009) argue for joint action by the International Monetary Fund and the WTO - the latter's participation required because the IMF has no ability to enforce its policy prescriptions on a member such as China that is not requesting IMF loans. However, use of trade restrictions to force an exchange-rate appreciation would represent a major shift in the mission of the GATT/WTO, which normally focuses on measures that affect the composition of trade flows rather than aggregate imbalances (Bown and McCulloch, 2009). Moving in this direction would open the door to further actions whenever a country's exports seemed "too large" or imports "too small"- according to criteria still to be determined.

Some argue that by maintaining a low international price for the yuan, China is in effect subsidizing its exports, and that a countervailing duty equal to the extent of yuan undervaluation would be appropriate under WTO rules. However, there is no consensus among economic experts on the extent of yuan undervaluation. Moreover, an analysis by Staiger and Sykes (forthcoming) raises analytical doubts concerning this approach. 
Staiger and Sykes conclude that the difficulty of determining the trade effects of China's currency practices "calls into question the wisdom and legitimacy of countermeasures that have been proposed..." In any case, even a large revaluation of the yuan in terms of the dollar would not be enough to restore bilateral balance between China and the United States unless accompanied by a substantial, sustained increase in national saving in the United States and a corresponding reduction in China and other surplus countries.

6.3 The trend toward preferential trading. Sharply contrasting with the absence of progress in multilateral trade negotiations is continued momentum in the negotiation of new preferential agreements. The attraction of moving in this direction is obvious-with a small number of participants it is much easier to craft terms that are mutually beneficial. While excluded countries as a group may be harmed, this effect is usually sufficiently dispersed to avoid any major fallout. Yet even the most ardent supporters of the preferential approach see it as a complement to multilateral liberalization rather than a substitute. The real challenge is to avoid creating a thicket of inconsistent policies that further complicate the task of achieving liberalization multilaterally (Baldwin 2006). Plummer (2007) advocates a multi-layered liberalization process in which regional agreements are based on "best practices" (the lasagna bowl). These might include a requirement that PTAs accept new members, perhaps after an initial waiting period. Kawai, Petri, and Sisli Ciammara (2009) and Lawrence (2008) envision the evolution of the WTO into a host organization for regional "clubs" formed by subsets of its members. In contrast to the current laissez-faire approach toward PTAs, the WTO could develop 
and enforce guidelines for club actions and also serve as a neutral arbiter of disputes arising among club members.

The tension between preferential trading and multilateral liberalization is greatest in the case of poor countries that are the beneficiaries of one-way preferences. While it may be laudable to bend WTO rules in a way that ensures gains for even the poorest participants, there may be other ways to achieve this goal without creating built-in opposition to multilateral liberalization (which reduces the value of trade preferences). One approach that has received increasing attention in recent years is aid for tradeprovision of resources that help poor countries achieve gains from trade, through measures ranging from expert assistance in identifying areas of comparative advantage to improvements in port facilities and customs procedures. Measures of this kind facilitate mutually beneficial trade by accelerating the integration of poor countries into world markets, rather than creating an artificial advantage for a particular group of exporters. Another approach is to maintain the model of a single undertaking, but, as in the Uruguay Round, allow developing countries a longer period in which to achieve compliance. A third option is to focus MFN tariff-cutting efforts on the goods of greatest interest to developing country exporters.

6.4 Trade and climate change. Reconciling WTO rules with national policies to limit greenhouse gas emissions is sure to pose a major challenge for the world trading system. Countries contemplating across-the-board action to reduce emissions face strong domestic political opposition, especially from industries whose costs will rise significantly as a consequence. Unless all countries adopt comparable measures, national 
policies raise obvious concerns about lost international competitiveness in the short run and migration of high-emissions industries to other countries in the longer run-in either case severely undermining the effectiveness of national actions in reducing global emissions. Policy proposals have therefore typically included border measures (taxes and subsidies intended to neutralize the impact on trade competitiveness) as well as government subsidies intended to reduce the private cost of complying with new standards or to spur innovation.

Hufbauer, Charnovitz, and Kim (2009) identify the areas in which national climate-change policies currently under review are most likely to conflict with WTO principles and thus result in a surge of new WTO disputes. These authors argue for negotiating a Code of Good WTO Practice on Greenhouse Gas Emissions Controls that would create a "green policy space" within which WTO members could take appropriate measures to limit emissions. In principle, the green space would allow countries some leeway within WTO rules to maintain the competitiveness of their own industries while raising environmental standards. At the same time, the Code would prevent the misuse of environmental policies to discriminate against goods and services produced abroad or to favor imports from preferred source countries.

A related and more immediate issue concerns trade policies toward green goods and services - the inputs used to reduce greenhouse gas emissions. Negotiations on trade in green goods and services are on the Doha Round agenda, and Pascal Lamy, DirectorGeneral of the WTO, argues that WTO members have a strong interest in opening their markets to such goods as a way to improve the efficiency of their economies. ${ }^{24}$ But

\footnotetext{
${ }^{24}$ Reuters, "WTO’s Lamy sees trade pact boosting green goods," May 20, 2010, http://www.reuters.com/article/idUSLDE64J13F20100520 (accessed 5/26/2010).
} 
Lamy's argument applies equally to liberalizing imports of almost any type of industrial input, and it thus ignores the need to overcome opposition from competing domestic producers. In practice, such a negotiation is likely to be complex and protracted, beginning with the determination of exactly which goods and services should be included.

Compared to other environment-related policies that have generated past WTO disputes (e.g., protection of dolphins and turtles), both costs and benefits associated with efforts to limit climate change are likely to be very large, and their effects experienced over many economic sectors. For these reasons, such a negotiation is urgent. However, finding the necessary common ground for agreement in a large and diverse group of nations is sure to be difficult—perhaps the largest challenge yet for the international trading system.

\section{Looking ahead}

This chapter has reviewed the evolution and structure of the GATT/WTO system as well as several emerging issues likely to affect its performance in achieving its various goals. However, the current state of the international trading system provides good reasons for optimism. Most important, the system has survived more or less unscathed the worst global economic conditions since the Great Depression and the inevitable resurgence of protectionist sentiment worldwide. WTO disciplines, backed by the dispute settlement mechanism, remain a potent safeguard against unchecked unilateral measures to limit foreign competition. Despite some increase in (GATT-legal) temporary protection, trade flows have rebounded vigorously as world economic growth has 
revived. But as discussed in the previous section, the system has yet to deal with some pressing issues. Thus, the status quo, while representing an important achievement in terms of multilateral cooperation, will not be enough to maintain the open and predictable market access that WTO members have come to expect.

Can the necessary progress be made? In the past, U.S. hegemony played a key role in shaping international institutions, but the United States does not appear ready to assume anything beyond shared responsibility for the provision of global public goods. New problems have also been raised by the emergence of large and economically powerful developing countries, such as China, India, and Brazil. Still poor relative to the United States and other industrialized countries, these countries are reluctant to participate in international agreements on the same terms as their much richer counterparts, yet their impact on the global economy and on global emissions is too large to be exempted without undermining the overall effectiveness of the system. The solution may lie in a two-part strategy that builds on the success of the WTO via completion of the Doha Round while also dealing flexibly with some complex issues by building from the bottom up, i.e., by channeling PTA formation and expansion along lines that provide a clearer path toward multilateral liberalization. 


\section{References}

Baldwin, Richard E. (2006). "Multilateralizing Regionalism: Spaghetti Bowls as Building Blocs on the Path to Global Free Trade." The World Economy, 29(11), 14511518.

Baldwin, Robert E. (2009). "Standstills in GATT/WTO trade negotiations are not all that unusual.” VoxEU.org, December 15.

Bown, Chad P. (2009). Self-Enforcing Trade: Developing Countries and WTO Dispute Settlement. Washington D.C.: The Brookings Institution.

Bown, Chad P. and Hiau Looi Kee (2010). "Trade Barriers, Developing Countries, and the Global Economic Crisis," World Bank working paper, May.

Bown, Chad P., and Rachel McCulloch (2009). "U.S.-Japan and U.S. China trade conflict: Export growth, reciprocity, and the international trading system." Journal of Asian Economics, 20(6), 669-687.

Bown, Chad P., and Rachel McCulloch (2010), "Developing countries, dispute settlement, and the Advisory Centre on WTO Law." Journal of International Trade \& Economic Development, 19(1), 33-63.

Crowley, Meredith A. (2003). "An introduction to the WTO and GATT." Economic Perspectives, $4^{\text {th }}$ Quarter, 42-57.

Dam, Kenneth W. (1970). The GATT: Law and International Economic Organization. Chicago: University of Chicago Press.

Estevadeordal, Antoni, Caroline Freund, and Emanuel Ornelas (2008). "Does Regionalism Affect Trade Liberalization toward Nonmembers?" Quarterly Journal of Economics 123(4), 1531-1575. 
Hoekman, Bernard, and Michel Kostecki (1995). The Political Economy of the World Trading System. Oxford: Oxford University Press.

Hoekman, Bernard, and Michel Kostecki (2009). The Political Economy of the World Trading System, third edition. Oxford: Oxford University Press.

Hoekman, Bernard, Will Martin, and Aaditya Mattoo (2009). "Conclude Doha: It Matters!” World Bank Policy Research Working Paper 5135, November.

Hudec, Robert E. (1998). "The Role of the GATT Secretariat in the Evolution of the WTO Dispute Settlement Procedure," in Jagdish Bhagwati and Mathias Hirsch, eds., The Uruguay Round and Beyond: Essays in Honor of Arthur Dunkel. Springer-Verlag, 101-120.

Hufbauer, Gary Clyde, Steve Charnovitz, and Jisun Kim (2009). Global Warming and the World Trading System. Washington, DC: Peterson Institute for International Economics.

Hufbauer, Gary Clyde, Jeffrey J. Schott, and Woan Foong Wong (2010). "Figuring Out the Doha Round." VoxEU.org, February 22.

Irwin, Douglas A. (2002). Free Trade under Fire. Princeton, NJ: Princeton University Press.

Jones, Kent (2010). The Doha Blues: Institutional Crisis and Reform in the WTO. New York: Oxford University Press.

Kawai, Masahiro, Peter A. Petri, and Elif Sisli Ciamarra (2009). “Asia in Global Governance: A Case for Decentralized Institutions.” ADBI Working Paper No. 157 , October. 
Krueger, Anne O. (2007). "An enduring need: multilateralism in the twenty-first century." Oxford Review of Economic Policy, 23(3), 335-346.

Lawrence, Robert Z. (2008). "International Organisations: The Challenge of Aligning Mission, Means and Legitimacy,” The World Economy 31(11), 1455-1470.

Martin, Will, and Patrick Messerlin (2007). "Why is it so difficult? Trade liberalization under the Doha Agenda." Oxford Review of Economic Policy, 23(3), 347-366.

Mattoo, Aaditya, and Arvind Subramanian (2009). "From Doha to the Next Bretton Woods: A New Multilateral Trade Agenda.” Foreign Affairs, 88(1), 15-26.

McCulloch, Rachel (1983). "The Tokyo Round and the Future of the GATT." Portfolio, $8(2)$.

McCulloch, Rachel, and Peter A. Petri (1997). "Alternative Paths Toward Open Global Markets," in Keith E. Maskus, Peter M. Hooper, Edward E. Leamer, and J. David Richardson, eds., Quiet Pioneering: Robert M. Stern and His International Economic Legacy. Ann Arbor: University of Michigan Press, 149-169.

Plummer, Michael (2007). “ ‘Best Practices’ in Regional Trading Agreements: An Application to Asia." The World Economy, 30(12), 1771-1796.

Pomfret, Richard (2007). "Is Regionalism an Increasing Feature of the World Economy?" The World Economy, 30(6), 923-947.

Staiger, Robert W., and Alan O. Sykes (forthcoming). “ 'Currency Manipulation' and World Trade." World Trade Review. 